\title{
HUMAN RIGHTS ADVOCACY IN MALAYSIA: THE CASE OF THE SUARA RAKYAT MALAYSIA (SUARAM)
}

\author{
Khoo Ying Hooi
}

\begin{abstract}
This paper is inspired by an interest to understand the roles and contributions of human rights advocacy groups to Malaysia and society. It aims to assess their effectiveness in advocating human rights, and the limitations that they face by referring the SUARAM as the case study. SUARAM has over the past two decades become one of the visible non-state actors in the country in its role to achieve better human rights protection. This study is concerned with how SUARAM has evolved, with special focus on its work in the area of civil and political rights. Despite changes in the political landscape of the country and the increase of civil actions and public awareness on the work of civil society groups, this paper argues that they can claim little achievements for the past years of human rights activism due to the rigid government policy, the non-human rights friendly legislation, and also its own internal organizational weaknesses. One significant aspect is the close link of human rights advocacy groups with the political parties that can lead to problems of credibility and transparency.
\end{abstract}

Keywords: SUARAM, human rights, civil and political rights, civil society, political parties

\section{INTRODUCTION}

The history of human rights in Malaysia can be well described as a history of progress and retrogression: of moving one step forward, moving two steps backwards. ${ }^{1}$ Despite the early introduction of liberal political institutions based on the Westminster system, there appear the elements of uneven and restricted in the distribution of civil, political and socio-economic rights in the country. ${ }^{2}$ The issue of human rights is a highly contentious topic, debated by various parties including 
policymakers, scholars, political activists and individuals. Increase in awareness to the significance of human rights within the society has been more apparent since late 1970s with the emergence of human rights advocacy groups.

At the national level, much of the debate revolves on civil and political rights, for instance, legislations that do not guarantee protection of fundamental rights and freedoms of Malaysians. One of the key legislations is the now repealed Internal Security Act (ISA), but has been replaced with the Security Offences (Special Measures) Act 2012 (SOSMA). ${ }^{3}$ Some other human rights violations evolve around the issues such as abuse of police powers, violations of freedom of association and peaceful assembly, electoral process which is not free and fair, legislature that is heavily executive-controlled and a non-independent judiciary. The government considers the human rights protection as a threat to their stability rather than a fundamental premise for their legitimacy.

At the international level, the debate on the universality of human rights has involved many countries in the Southeast Asia region, particularly governments with different ideological positions. They manipulate the right to national self-determination as a defense against other States attempting to interfere in their internal affairs. These countries, including Malaysia, have called for a system of human rights that emphasizes Asian values. ${ }^{4}$

As human rights issues becomes more important, a growing number of groups and organizations are likely to identify itself with this discourse. In fact, a broad range of groups is already engaged in activities relevant to the defense or promotion of human rights. Malaysia provides a good example where diverse ethnic, religious, and cultural backgrounds offer an opportunity to demonstrate how these factors would interact and shape different forms and views on civil society.

\section{DEFINITION OF KEY TERMS}

The purpose of this paper is two-fold. First is to assess the effectiveness of SUARAM in advocating human rights. Second is to analyze the limitations that they face. Before going in depth into the subject matter, it is important to look into the concept of civil society. Civil society is 
often associated with the quality of governance, ability to empower public participation and capacity to sustain a healthy democracy. ${ }^{5}$ The civil society is also described as the 'third sector' or the 'third force'. Diamond defines civil society as the "realm of organized social life that is open, voluntary, self-generating, at least partially self-supporting, and autonomous from the state and bound by a legal order or a set or shared values."

Simply put, this is based on the argument that civil society organizations bolster the performance of the polity and strengthens democratic governance. Like Diamond, Clarke lists out three ways whereby the proliferation of non-governmental organizations strengthens the civil society movement. First, it promotes and upholds reform of the state. Second, it organizes and mobilizes the disempowered social strata, and third, it supplements the traditional institutions of democracy. ${ }^{7}$

In Malaysia, human rights non-governmental organizations are often seen as opposing the State's national interest and as such considered as a threat. In current political discourse, advocacy groups often act as a buffer between the state and its citizens. ${ }^{8}$ They play a significant role in establishing and maintaining a rights-based society and are generally deemed as the catalyst to improve the quality of governance and democracy, also to strengthen people power and enable development.

\section{THE POLITICAL SYSTEM IN MALAYSIA}

The Federation of Malaya achieved its independence from the British colonial rule on 31 August 1957. Other than the pressure asserted by the nationalists and anti-colonial movements of varying persuasions, it should be noted that the independence would not have been achieved without the mutual compact agreed between Britain and the domestic ruling class. The compact, often referred to as the 'Merdeka compromise', allowed the ruling class to dominate and govern Malaya. ${ }^{9}$

Malaya was later on re-constituted into a larger entity with the incorporation of Singapore and the Bornean states of Sabah and Sarawak in 1963. However, Singapore was expelled from Malaysia in 1965. Malaysia has the basic features of a parliamentary system 
of government that is modeled on the Westminster parliamentary system, with periodic multi-party elections and constitutionally defined separation of powers entrusted in the executive, legislative and judiciary.

The Federal Constitution, in a way, was embraced to achieve a balance between the various communities in Malaysia. The main features of the Constitution are a dual government, at the same time practicing a Westminster-styled separation of powers, whereby the executive is included as part of the legislature and an independent judiciary, a monarch elected by a constitutionally protected group of Sultans, special privileges for Malays and natives of Sabah and Sarawak, and provision of extensive emergency powers. ${ }^{10}$ The Federal Constitution has been amended several times since its enactment. The second part of the Constitution provides a provision to protect fundamental liberties, which includes the liberty of the person, equality before the law, freedom of movement, freedom of speech and expression, freedom of association and assembly and freedom of religion. All of these liberties are not guaranteed but they are subjected to the Constitution as well as the ordinary laws. ${ }^{11}$

After more than five decades of independence, many ambiguities in the actual practice of the idea of democracy surfaced and deepened from time to time. It is undeniable that the heterogeneous nature of the population and the tendency for every political issue to be transformed into communalism is a significant feature in Malaysian socio-political context. ${ }^{12}$ Three essential components in an ideal democracy are extensive political competition, a high level of political participation and guaranteed civil and political rights. ${ }^{13}$ The imposing of legislations with anti-democratic elements indicate that Malaysia is more of a 'quasi democracy' since it practices Westminster democracy partially. ${ }^{14}$

The political system in Malaysia is often discussed between the nature of democracy and authoritarianism. It is also often referred to as 'soft authoritarianism', ${ }^{15}$ or 'semi-democracy'. ${ }^{16}$ Since 1955, the Alliance regime or the Perikatan until 1969 and Barisan Nasional (BN) or National Front has been the only coalition party dominating government since the independence. This coalition is comprised primarily of communal parties representing Malaysia's major ethnic groups: Malays, Chinese and Indians. Government under the BN 
combines democratic elements with significant restrictions on individual rights. Despite relative freedom to form political parties, the opposition parties' activities are often constrained by the overall legal environment. ${ }^{17}$

\section{BACKGROUND OF THE SUARAM}

The SUARAM, which literally means 'Voice of the Malaysian People' was established as a response to the Operasi Lalang incident on 27 October 1987, where some 106 members of opposition parties, educationists, activists and other individuals were detained without trial under the ISA ${ }^{18}$ because they were categorized as a 'threat to national security'. Among those arrested were Lim Kit Siang, the late Karpal Singh, and Dr. Chandra Muzaffar. The former Prime Minister, who was also Minister of Home Affairs at that time, Tun Dr. Mahathir Mohamad, initiated this massive crackdown when he faced internal pressure within his United Malays National Organization (UMNO). Instead, he and the official Ministry of Home Affairs' White Paper entitled Towards Preserving National Security, issued in 1988, have accused most of the detainees of racial and religious extremism. ${ }^{19}$

In response, seventeen non-governmental organisations formed the ISA Detainees' Family Support Group to campaign for the release of these ISA detainees. The usage of SA as a method to silent dissent voices sent a signal that the country needed a more properly structured organization to monitor human rights, to provide supports to the detainees and their family, and most importantly to repeal the ISA. ${ }^{20}$ The mass arrests and the political unrest stimulated the politicization of the NGO community by bringing NGO activists together in the prison. ${ }^{21}$ The ISA Detainees' Family Support Group, ISA detainees and other non-governmental organizations' activists subsequently established SUARAM in 1989 with the objective to defend and uphold human rights particularly to campaign for the abolition of the ISA. Some of the key activists associated with the SUARAM include Sivarasa Rasiah, ${ }^{22}$ Dr. Nasir Hashim, ${ }^{23}$ and Dr. Kua Kia Soong. The Detainees' Family Support Group, which consisted of Mrs. Anne Kua, the wife of Dr. Kua and Mrs. Anizan Isahak, the then wife of Dr. Nasir, played a significant role in the establishment of the SUARAM. ${ }^{24}$ 
During its early establishment, the SUARAM focuses on civil and political rights with a specific focus on preventive laws such as the ISA in view of the context in which it was formed. From time to time, the focus widened to also include other human rights issues such as the workers' rights, indigenous peoples' land rights, ${ }^{25}$ rights of refugees and asylum seekers. Some other campaigns include issues on environmental issue, deaths in custody; accountability and transparency, freedom of information, press freedom, freedom of assembly and association, as well as freedom of expression and speech. The SUARAM also engages in specific advocacy activities include conferences and seminars, publications, public protests and demonstrations.

The SUARAM has established itself in the last two decades as a major human rights resource center and a leading activist organization in the country. It is a non-profit organization working towards a free and equal society by fighting for civil liberties that are enshrined in the Universal Declaration of Human Rights 1948 (UDHR) and the Malaysian Human Rights Charter 1993 which enable public active participation and the fruition of a civil society in Malaysia.

On December 10, 1992, several NGOs came up with the idea of a Malaysian human rights consultation as they felt there was a need for human rights standard which was relevant and appropriate for the situation in Malaysia. ${ }^{26}$ This is also to create networking and to promote unity among the NGOs' circle. ${ }^{27}$ An organizing committee was formed and a questionnaire on various aspects of human rights in Malaysia was distributed to about 450 Malaysian organizations for feedbacks. ${ }^{28}$ As the result, the Malaysian Human Rights Charter 1993 was produced and endorsed by some 50 NGOs which include human rights organizations, trade unions, academic bodies, women's groups, environmental organizations, consumer associations and other non-state sectors.

The Charter advocates a human rights ideology, based on the universality, interdependence and indivisibility of human rights. The group has engaged the government in the debate on Asian values and attempted to respond to the propaganda on human rights discussion raised from the Malaysia, ${ }^{29}$ particularly from the former Prime Minister, Tun Dr. Mahathir Mohamad. 
In 1989, there was only one full time staff in the SUARAM assisted by several Secretariat members in volunteer basis that consisted of different communities, which handled on administration, training and so forth. The SUARAM's main office is based in Petaling Jaya and it has two other supporting groups based in Penang and Johor Bharu situated in the northern and southern region of Peninsula respectively.

The SUARAM also has a segment on Friends of SUARAM (FOS), allowing concerned members of the public to participate in the fight for human rights. Help can be extended in the form of donation to assist in project costs, publishing of educational materials, seminars and campaigns efforts. The work of volunteers is important to the SUARAM as well. These volunteers assist the staff of the SUARAM mainly on campaigns, as well as documenting and monitoring, research, publishing of reading materials, and others.

The activities of the SUARAM can be divided into few areas such as monitoring and documentation, human rights campaign, human rights support, coalition building and international solidarity. In carrying out its activities, the SUARAM monitors, documents, exposes and opposes human rights violations by the Malaysian authorities. The work consists of gathering information from victims of human rights abuses and monitoring news, political driven reports and the media.

The SUARAM publishes its annual human rights report and other human rights related publications ${ }^{30}$ Based on the Malaysian Human Rights Charter 1993, a consultation of Malaysian non-governmental organizations was held on 24 April 1994 at the Furama Hotel in Kuala Lumpur to prepare a human rights report. The first and the most comprehensive status report of human rights recorded the human rights abuses which had taken place in the country and at the same time raise awareness to human rights concerns among the Malaysian public $^{31}$ and it has since become an annual publication and a main priority in the SUARAM's calendar. At the same time, the SUARAM also act as a watchdog to the Human Rights Commission of Malaysia (SUHAKAM) ensuring it carries out its function in the promotion and protection of human rights in Malaysia.

Internet especially social media is the main tool for the SUARAM to feature regular updates. On certain issues, the SUARAM 
produces media statements or petitions or urgent appeals on its own motion. Besides that, the SUARAM also practice joint effort or coalition approach in conducting its advocacy work. The SUARAM also functions as an information center for human rights issues. It organizes and participates in fact-finding missions, as well as training on monitoring and documentation for other non-governmental organizations. ${ }^{32}$ The SUARAM also produces monitoring report on the performance of the SUHAKAM. The SUARAM has produced monthly newsletter called, E-Hak. Nevertheless this effort is not consistent after several months.

In addition, the SUARAM campaigns on a number of issues including the abolition of draconian laws such as the ISA, freedom of assembly and abuse of police powers. It provides human rights information and education to the public. Some of the methods include distributing pamphlets, organizing road shows, public forums, seminars, trainings and the Internet. ${ }^{33}$ The SUARAM has developed its own training tools for certain issues such as the abuse powers of police.

The SUARAM also intervenes and supports victims and their families whose basic rights have been violated such as in the cases of arbitrary arrests and detention, eviction and abuses of police powers. Other than that, it renders its assistance to the marginalized communities such as the urban poor, students, indigenous peoples, refugees and asylum seekers. ${ }^{34}$ The SUARAM frequently sends urgent appeals on the human rights situation in Malaysia for immediate action and sometimes implement an Urgent Arrest Team to monitor and help those who are arrest during the peaceful assembly, provide legal advice, media assistance and the reference purposes.

In term of networking, it builds its vast network with other social interest groups involved in human rights, labour issues, gender, environment, indigenous people and other issues of common interest. The SUARAM is among the 60 civil society organizations known as 50:44 that issued the 'Civil Society Joint Statement on Restoring Democracy', at the opening of its 11-day Merdeka celebration programme, calling for the preservation and enhancement of human rights and basic freedoms, which based on values of participation, accountability, transparency, equality and diversity. About 30 civil societies, including the SUARAM, collaborated to hold a series of 
events under the theme, 'Remembering the People that Build the Nation'. ${ }^{35}$ Apart from being one of the endorsees in the Coalition for Clean and Fair Elections (BERSIH), the SUARAM also serves as the coordinator and participate aggressively in the Coalition of Malaysian NGOs in the UPR Process (COMANGO) that is banned by the government.

It is seen as one of the most outspoken human rights groups in Malaysia. At the regional and international level, the SUARAM campaigns for human rights in the region, especially in Southeast Asia such as Indonesia, Timor Leste, Aceh, Myanmar and Singapore. The SUARAM networks with regional organizations such as Forum Asia for Human Rights and Development (FORUM Asia), Asian Human Rights Commission (AHRC), Asia-Pacific Human Rights Facilitating Team, Asia Pacific Coalition for East Timor, Asia Pacific Women in Law and Development ${ }^{36}$ and the International Federation for Human Rights (FIDH).

\section{SUARAM'S ADVOCACY}

It is common that non-governmental organizations especially those striving to protect and uphold human rights find it difficult to register as an organization under the Societies Act 1966 as the Registrar of Societies (ROS) is uncommonly slow in registering any human rights-based organizations. ${ }^{37}$ Due to the delay and hindrance by the authorities, the SUARAM had to register itself as a lawful body under the Registration of Companies Act $1965 .{ }^{38}$ Its vision statement is to work for a society that is peaceful, free, equal, just and sustainable by empowering people and building a mass movement to uphold human rights. SUARAM's mission is to establish a human rights movement by building support and unity of the people; empowered by public support. ${ }^{39}$

Since its inception in 1999, the SUARAM presents its annual Human Rights Awards to a community or group that has been outstanding and inspiring in their efforts to promote and protect human rights in conjunction with the International Human Rights Day on December 10. Since the inaugural award was presented in 1999, the winners have been diverse in their causes, but all of them have overcome tremendous hardships and tribulations in the fight for 
human rights. The objectives of this event is to give recognition to the struggles for human rights of local communities, to promote and introduce the diverse nature in human rights work to Malaysians from all walks of life, as well as to encourage and strengthen cooperation between groups working on human rights in Malaysia. ${ }^{40}$

The SUARAM is also involved with the environmental issues such as the People before Profits project, as well as Bakun Dam project. However in this paper, the focus is solely on the national issues of civil and political liberties. In term of funding, the SUARAM is funded by donations and grants from public as well as private sources. Some core sources come from private donations, local fund-raising events, book sales and campaign merchandise. ${ }^{41}$ The SUARAM's policy on accepting funds is that donors must not interfere with decision-making, policies and programme of the SUARAM. ${ }^{42}$ The source of the SUARAM's funding is also heavily depending on the foreign resources such as International Republican Institute (IRI) and National Endowment for Democracy (NED) based in the United States of America.

One of the main priorities of the SUARAM is to urge the Malaysian government to abolish laws that allowed for detention without trial. Most notably is the now repealed ISA. The ISA was initially created to battle the communist insurgency in the 1960s. It was subsequently used against those parties with dissenting voice, as well as the students.

In its past effort on the abolishment of ISA, the SUARAM used a few methods such as the publication on the guidebook for the families of the ISA victims through the formation of Abolish ISA Movement (GMI) in April 2001 after the arrest of ten leaders from the Reformasi movement. There are 83 member organizations in GMI and the SUARAM acts as the Secretariat for GMI. The SUARAM and GMI collaborate together in handing memorandum at most of the time.

The SUARAM also wrote letters to the police enquiring about statistics for arrest, detention and prosecution of persons under the ISA frequently for the purpose of monitoring and documentation. However, the police rarely respond to SUARAM's enquiries. The SUARAM also issued statements condemning ISA arrests such as during the arrest 
of Anwar Ibrahim, where the SUARAM was among the first to issue a statement condemning it.

During the 1999 General Election, the SUARAM and 50 nongovernmental organizations, as well as 2,000 former ISA detainees urged the election candidates to support the abolishment of ISA in their agenda. The now defunct Alternative Front which was a coalition made up of four opposition parties in Malaysia has given their solemn promise to abolish the ISA in their election manifesto. ${ }^{43}$

In 1999, the SUARAM also launched a book by Koh Swee Yong entitled 40 Years of the ISA, which documented the experiences of the ISA detainees. The work was originally written in Chinese, but has also been translated into the Malaya language as well as English. ${ }^{44}$ Other than that, the SUARAM also published a book by Dr. Kua Kia Soong who is also the Chairman of SUARAM, entitled 445 Days under Operation Lalang in 2000.

Finally on the Malaysia Day in 2011, Prime Minister Najib announced the repeal of ISA and three other emergency declarations. However the introduction of Security Offences (Special Measures) Act 2012 that replaced the ISA has again drew attention of GMI.

Apart from that, the SUARAM is also actively involved in pushing for the government to address the issue of police brutality and deaths in custody. The SUARAM normally receives complaints from the families of the victims and it will issue press statement or hold protest against the relevant agencies. Many complaints of abuse of power by the police have been made but actions taken have been few and far in between. Normally, the SUARAM receives complaints from the public that police are corrupt, rude and violent.

In addition, the SUARAM also organizes training and workshops related to the issues of police brutality and have also published some pamphlets and booklets to educate the public on the abuse of police powers.

Another issue that the SUARAM focuses on is the freedom of association and assembly. The SUARAM has its own share of experience with police barring them from assembly; for example at a forum organized by the SUARAM in October 1998 to commemorate 
police stopped the Operation Lalang in 1987 and the 300 participants were ordered to leave the forum. A similar incident occurred in a dinner event organized by SUARAM to commemorate the 50th Anniversary of the UDHR. There was an attempt by the police to bar the event, however after some discussion with the police; they were allowed to continue with the event.

The active involvement of the SUARAM in the issue of free and fair elections starts from the 1999 National Election. In May 1999, 42 Malaysian non-governmental organizations made a joint effort to establish Malaysian Citizen's Election Watch (PEMANTAU), an independent election observer team to prevent the corruption and abuse of powers. The Steering Committee of PEMANTAU was made up of eight representatives from the participating non-governmental organizations which consist of the SUARAM, Pertubuhan Kebajikan BUDI Malaysia (BUDI), Aliran Kesedaran Negara (ALIRAN), Angkatan Belia Islam Malaysia (ABIM), National Human Rights Society (HAKAM), the International Movement for a Just World (JUST), and Pertubuhan Jemaah Islah Malaysia (JIM). The Civil Rights Committee of the KLSCAH was assigned the responsibility of liaising with the Chinese community. ${ }^{45}$

The PEMANTAU, together with some international election observer organizations which includes the National Democratic Institute (NDI) and the Asian Network for Free Elections (ANFREL) carried out independent observation and monitoring during the general election. Their observations were compiled in the Interim Report on the 1999 Malaysian General Election, which has been released to the Election Commission, local political parties as well as Election Watch organizations overseas. However the report was rejected by the EC without any considerations. ${ }^{46}$

The establishment of the PEMANTAU has received significant positive response from various sectors of the society and it has also received a lot of volunteers as observers for the elections. However, the application to be recognized formally as observers in the elections was denied by the EC. The SUARAM is also a member organization in the most talked about electoral reform movement, the BERSIH, a coalition of 89 Malaysian civil society organizations. 


\section{ANALYSIS}

Progress in addressing human rights concerns in Malaysia is the product of decades of struggles for human dignity by Malaysians, individually and collectively. There is a need to mainstream human rights in Malaysia particularly on the area concerning civil and political rights. The various principles of human rights should be the foundation of Malaysian culture. Consequently, there is the need to recognize that the connotation of human rights is not negative or anti-government.

The influence of non-governmental organizations such as the SUARAM must not be underestimated as it embodies the human rights conscience of the community and represent an important element of the civil society movement.

It is undeniable that at this cyber age, websites have allowed people access to alternative information bypassing the institutional media. Information has enabled the mobilization of people. The Internet and other emerging network technologies provide powerful tools to support non-governmental organizations' work like the SUARAM. The advances of information and communication technologies, specifically the Internet can contribute in helping to advocate civil and political rights in the country. Comparing with 20 years ago, now it is much easier for the organization to channel the human rights information to the public. People turn to the Internet for alternative information when they do not trust the official version of events.

In some events, the SUARAM has successfully utilizing alternative media to mobilize large-scale collective action such as street demonstrations and legislative lobbying. Nevertheless, the fact that many laymen in rural areas are yet to familiar with the technologies trend has apparently left out in these advocacy activities.

As Wiseberg stressed, human rights non-governmental organizations perform "two absolutely indispensable functions": information gathering, evaluation and dissemination; and keeping the political process open or creating political space for democracy forces. ${ }^{47}$ These organizations play a significant role in the society and act as a vehicle for the protection of human rights, and are also a vital ingredient for a democratic society. There has been relentless propagation of political agendas by non-governmental organizations 
to galvanize and politicize citizens. The civil and political rights advocacy process spearheaded by non-governmental organizations in Malaysia seems to have been also revived and redoubled in recent decades. Still, the chances for them to achieve their demands depends largely on how open and susceptible the State and society are to the information received.

There has been little substantive progress in terms of protection of political and civil liberties. The most salient point has been the campaign on the abolishment of the ISA, the major reason of the establishment of SUARAM in 1989 after the Operation Lalang incident in 1987. The formation of the GMI has particularly taken center-stage in the country on ISA advocacy and now the attention shifts to SOSMA.

On another hand, the government's particular resentment of rights-based challenges and the lack of strategic vision and sustained organizational development within SUARAM itself have so far hindered the human rights movement from having a more substantial impact.

The role and impact of non-governmental organizations have to be understood within the context of the country's political and social development. It is apparent that since the Reformasi movement in 1999 and the political tsunami on 8 March 2008 as well as the 2013 polls, the involvement of local human rights non-governmental organizations has been gaining attention in and out of Malaysia. The term civil society movement and the activities associated particularly to SUARAM are raised in the country's Parliamentary debate.

The most significant factor restricts the development of advocacy-oriented non-governmental organizations like the SUARAM is Malaysia's regulatory environment. Although Article 10 of the Federal Constitution guarantees freedom of speech, expression, peaceful assembly and association, these rights may be limited in the interests of political order. The legal framework governing nongovernmental organizations is the Societies Act, the Police Act and a range of other laws restricting speech, the press and assembly including the new Peaceful Assembly Act 2012. These range of laws, old and new curtail non-governmental organizations' efforts and discourage would-be supporters. 
Most human rights non-governmental organizations, which are politically engaged in the Malaysian context more or less share the perspective that democratic practice is enhanced by the plural presence of groups, championing issues which usually fall outside the parameters of mainstream politics and the work of political parties.

Some express concern that in recent years some civil society organizations such as the SUARAM, has aligned themselves too closely with the Pakatan Rakyat (PR). The fact that it is frequently allied with opposition political parties against the ruling government has colored the authorities' assessment of SUARAM in general, moreover with its involvement with the investigation of Scorpene submarine scandal. On this onset, the direction of the SUARAM has appeared to be inconsistent.

Advocacy for ratification and implementation is an important task of human rights non-governmental organizations, and it is hope to see further progress made. The non-governmental organizations are often among the first to reach the scene of massive violations of human rights and humanitarian law. The SUARAM potentially have a vital role to play through documented violations, drew attention to them, and by doing so, helped to bring a halt to the ongoing violations. However, there are significant limitations that the SUARAM faces. The SUARAM may have particular concerns regarding the protection of confidential relationships or sources as in Malaysia, the protection of human rights defenders are not well recognized and the latest is the act of government in banning the COMANGO with SUARAM as the coordinator.

Human rights non-governmental organizations have the flexibility and informal character, which subsequently encouraged the formation of coalitions and campaign groups on specific issues where several non-governmental organizations have worked together. The SUARAM as an individual organization has often opted for advocating certain human rights issues through coalition with other civil society organizations. These add extra resources, greater publicity and allow for mobilization from each of their own sectors. Examples of these are the Movement for Freedom and Justice and the Campaign for a Freedom of Information Act. 
Non-governmental organizations have been most effective when they work together in coalitions, pooling their resources and coordinating their lobbying efforts. One of the most prominent examples is the Bersih movement. Human rights advocacy groups use an array of tactics to try to persuade or pressure offending governments to stop human rights abuses. Their efforts may range from private diplomaticstyle approaches, to lobbying within international organizations, to highly organized publicity and letter-writing campaigns that directly involve the public. The human rights organizations in Malaysia have relied mainly on public initiatives such as local lobbying and public campaigning to apply pressure for human rights reform. While the SUARAM may occasionally irritate states with singing criticisms of their human rights practices, they can in fact do little to change their behavior or policies.

Used to undertaking projects mainly with only limited resources and imperfect information, non-governmental organizations are resourceful and willing to work with uncertainty which is the key element to succeeding in human rights issues. For example, SUARAM mounts a host of successful development projects without large offices, overhead funding or even a full complement of staff. The notion of social capital generated through these efforts, the network of trust has been built up from time to time through the participation of public in the events that organized by SUARAM such as fundraising campaigns, seminars and workshops.

Human rights non-governmental organizations have developed a reach, and are growing to a size which is unparalleled by most other organizations working within the field of civil and political rights. They are increasingly expanding their services and frontline offices in the country. For example, the SUARAM's headquarter is located in Petaling Jaya, Selangor. However, it also has an office in Penang and Johor. This is to reach communities that lack of infrastructure or funds to work with. As the most local groups available to tackle human rights issues, non-governmental organizations could also be the most able to mount a rapid response to sudden downturns in their areas. 


\section{CONCLUSION}

There is no adequate framework for assessing the effectiveness of a particular human rights organization. Just as there are different sorts of non-governmental organizations for different kind of issues, the same goes even within the human rights field. There are also different sorts of non-governmental organizations with quite distinct missions, techniques and organizational forms. Even when we restrict our attention to a few truly human rights non-governmental organizations on civil and political rights, notably, the SUARAM, Aliran Kesedaran Negara (ALIRAN), National Human Rights Society (HAKAM) and a few others, there are a significant diversity in goals, strategies, action techniques, and organizational forms. However, there is often also a significant area of overlap between the missions of various organizations around particular issues, so that it is often difficult to disentangle their separate influences from their cumulative influence on other political actors and sectors.

Non-governmental organizations, however, cannot work efficiently and effectively when many activities are curbed by a host of restrictive laws. The right to assemble peacefully, associate freely, obtain information and conduct public debate without fear of repression should be restored.

While Malaysian non-governmental organizations have grown and consolidated their operations, among their many issues and problems remain the scarcity of sufficient leadership and training, disagreements over methodology and direction, and ethnic divisions. But by far the major issue for Malaysian non-governmental organizations is the interventionist role of the State. In the Malaysian context, the State remains a highly dominant factor of civil society discourse and practice whether civil society elements desire it or not.

Little has been written about the human rights non-governmental organizations in Malaysia. The 2008 and 2013 national elections have indirectly impacted the development of civil society in the country including the SUARAM. Despite the widespread proliferation of non-governmental organizations self-regulatory initiatives over the past two decades, there has been no thorough stocktaking and analysis of existing initiatives. There is an urgent need for the SUARAM to strengthen its own internal structures and operation. 
Just like the other agencies, non-governmental organizations should be accountable to their stakeholders: peoples whose rights they seek to protect and improve; their own members, supporters and staff; to donors; to partner institutions, both governmental and nongovernmental; and, more importantly, also to the general public. The non-governmental organizations should also be able to demonstrate a democratic structure. They are required to practice participative approach in making decision and at the same time, also to adopt a non-partisan approach in order to gain confidence of the general public and legitimacy. They should focus on their key agenda and not o be controlled by donors' requests or any form of obstacles in their operational environment.

Although the SUARAM sometimes works on its own, the impact of their activity is greatly increased in joining with other civil society actors. With their mass membership in some other organizations, the SUARAM can be a powerful driver in opening up democratic space when they work in alliance with others. In this regard, the role of media is also crucial to engage public attention.

Non-governmental organizations are facing numerous of new challenges on performing their roles more effectively in an increasingly complex world. Realizing such condition, the non-governmental organizations have no choice but to step out from their comfort zone and become increasingly professional in dealing with matters. Having said that, this requires developing strong organizations, with solid structures and career-minded staff. Malaysia's human rights practice, by way of national laws and legal instruments, has steadily slid downhill since independence in 1957. Thus, one of the major challenges for the SUARAM remains the effective enforcement of human rights against government that is not willing to comply with their international human rights obligations and respective decisions and recommendations of international human rights monitoring bodies.

However, although the number of non-governmental organizations in Malaysia to some extent grew dramatically, this growth does not necessarily translate into a democratization process in all of them. In Malaysia, the notion of Asian values was used to limit its citizens' active political participation and to tightly regulate human rights advocacy non-governmental organizations. It is therefore simply impossible to 
make a drastic change on the situation of civil and political rights in Malaysia. However, if we focus on more modest and discrete changes, the SUARAM undoubtedly had some significant influence.

Ultimately then, non-governmental organizations will continue to be important vehicles as long as citizens need them to articulate their concerns and to help implement their needs. It can be expected that the SUARAM will stay play a significant role for some time to come. The most important thing is that it will need to undergo some so-called reforms within the organization as highlighted above. This process will undoubtedly take time.

\section{NOTES}

1 Cheah Boon Kheng, "From the End of Slavery to the ISA: Human Rights History in Malaysia," in Jomo K. S. (ed.), Reinventing Malaysia: Reflections on Its Past and Future, Bangi: Universiti Kebangsaan Malaysia (UKM), 2001, p. 57.

2 Vidhu Verma, Malaysia: State and Civil Society in Transition, Boulder: Lynne Rienner, 2002, p. 4.

3 The SOSMA was approved by the Malaysian Lower House or Dewan Rakyat on 17 April 2012 and gazetted on 22 June 2012. Under the SOSMA, initial police detention is cut to a maximum of 28 days, after which the Attorney General must decide whether to prosecute and on what charges. On the down side, judicial oversight is notably absent during the first 24 hours of police custody and such absence can be extended to the entire 28day investigatory period.

4 Verma, Malaysia, p. 167.

5 Lee Hock Guan, "Introduction," in Lee Hock Guan (eds.), Civil Society in Southeast Asia, Singapore: Institute of Southeast Asian Studies (ISEAS), 2004, p. vii.

6 Larry Diamond, Developing Democracy: Toward Consolidation, Baltimore: John Hopkins University Press, 1999.

7 Gerard Clarke, The Politics of NGOs in Southeast Asia: Participation and Protest in the Philippines, London: Routledge, 1998, p. 9.

8 Verma, Malaysia, p. 2.

9 Khoo Boo Teik, "Limits To Democracy: Political Economy, Ideology and Ruling Coalition," in Mavis Puthucheary and Norani Othman (eds.), Elections and Democracy in Malaysia, Bangi: Penerbit Universiti Kebangsaan Malaysia (UKM), 2005, p. 19. 
10 Tan Poh Ling, "Human Rights and the Malaysian Constitution Examined through the Lens of the Internal Security Act 1960," <http://www.abc.net. au/power/conference/tan.pdfs

11 Ibid.

12 Zakaria Haji Ahmad, "Malaysia: Quasi Democracy in a Divided Society," in Larry Diamond, Juan J. Linz and Seymour Martin Lipset (eds.), Democracy in Developing Countries: Asia, Vol. 3, Boulder: Lynne Rienner, 1989, p. 351.

13 Diamond, Linz and Lipset (eds.), Democracy in Developing Countries: Asia, p. xvi.

14 Zakaria Haji Ahmad, "Malaysia: Quasi Democracy in a Divided Society", p. 349.

15 Gordon P. Means, "Soft Authoritarianism in Malaysia and Singapore," Journal of Democracy, Vol. 7, No. 4, October 1996, pp. 103-117.

16 William Case, "Semi-Democracy in Malaysia: Withstanding the Pressures for Regime Change," Pacific Affairs, Vol. 66, No. 2, 1993, pp. 183-205.

17 Meredith, L. Weiss and Saliha Hassan, "Introduction: From Moral Communities to NGOs", in Meredith L. Weiss and Saliha Hassan (eds.), Social Movements in Malaysia: From Moral Communities to NGOs, London: RoutledgeCurzon, 2003, p. 6.

18 See SUARAM's website, http://www.suaram.net/

19 Committee against Repression in the Pacific and Asia (CARPA), Tangled Web: Dissent, Deterrence and the 27 October 1987 Crackdown in Malaysia, Australia: CARPA, 1988, p. xi.

20 Sivarasa Rasiah, National Human Rights Advocacy, Report of a Regional Consultation, Manila: Catholic Institute for International Relations (CIIR) and the Ateneo Center for Social Policy and Public Affairs (ACSPPA), 3-4 September 1999.

21 Gerard Clarke, The Politics of NGOs in Southeast Asia: Participation and Protest in the Philippines, London: Routledge, 1998, pp. 36-37.

$22 \mathrm{He}$ is co-founder of the SUARAM and currently serves as Vice President of the Parti Keadilan Rakyat (PKR) and Member of Parliament for Subang, Selangor.

${ }^{23}$ He is National Chairperson of the Parti Sosialis Malaysia (PSM) or Malaysian Socialist Party and former Member of Parliament for Kota Damansara, Selangor.

24 Interview with K. Shan in Kuala Lumpur, 27 November 2007. He was a former staff attached to the SUARAM, HAKAM and Amnesty International Malaysia (AIM). 
25 Rasiah, "National Human Rights Advocacy".

26 SUARAM, Malaysian Human Rights Report 1998, Petaling Jaya: SUARAM Komunikasi, 1998, p. 1.

27 Interview with Yap Swee Seng on 30 November 2007 in Petaling Jaya. He is the SUARAM Executive Director.

28 SUARAM, Malaysian Human Rights Report 1998, p. 1.

29 Rasiah, "National Human Rights Advocacy."

30 See SUARAM's website at <http://www.suaram.net/>

31 SUARAM, Malaysian Human Rights Report 1998, p. 1.

32 See the SUARAM's website at $<$ http://www.suaram.net/>

33 Interview with Yap, 30 November 2007.

34 See the SUARAM's website at $<$ http://www.suaram.net/ $>$

35 "Preserve Human Rights: Coalition," The Sun, 7 September 2007.

36 Ibid.

37 Yang Pei Keng, "Registration of Businesses (Amendment) Act 2001," INSAF, Vol. 32, No. 1, 2003.

38 Interview with Shan, 27 November 2007.

39 See SUARAM's website.

40 SUARAM, SUARAM to Present Human Rights Awards in Recognition of Outstanding Human Rights Defenders, 1 November 2007.

${ }^{41}$ Interview with Yap, 30 November 2007.

42 See SUARAM's website.

43 SUARAM, Laporan Khas Hak Sivil \& Politik Malaysia, 1995-1999, Petaling Jaya: SUARAM Komunikasi, 1999, p. 24.

44 Ibid., p. 8.

45 "Fair and Fair Elections? Reports, Petitions and the Election Commission, Aliran Kesedaran Negara," ALIRAN Online, $<\mathrm{http}$ ://www.aliran.com/oldsite/ monthly/2000/03b.html>

46 SUARAM, Malaysia: Human Rights Report 2002 on Civil and Political Rights, Petaling Jaya: SUARAM Komunikasi, p. 8.

47 Laurie S. Wiseberg, Defending Human Rights Defenders: The Importance of Freedom of Association for Human Rights NGOs, Montreal: International Center for Human Rights and Democratic Development, 1993, pp. 3-5. 